\section{School of Economics Working Paper 2016-04}

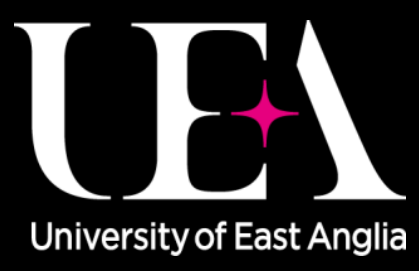

SCHOOL OF ECONOMICS

\title{
Mellowing with tenure? \\ Socialization increases prosocial behavior in public organizations
} by Sheheryar Banuri* Philip Keefer**

*School of Economics, University of East Anglia

**Inter-American Development Bank

\begin{abstract}
Recent research suggests that prosocial organizations are likely to have more prosocial employees, and that this match plays a significant role in organization contracting practices and productivity - for example, in government. Evidence suggests that selection plays a role: prosocial employees are more likely to join prosocial organizations. In this paper, we ask whether prosocial behavior increases with tenure in prosocial organizations. Using a unique sample of nearly 300 midcareer Indonesian public officials, we find that subjects with longer tenure in the public sector exhibit greater prosocial behavior.
\end{abstract}

School of Economics University of East Anglia Norwich Research Park Norwich NR4 7T J United Kingdom www.uea.ac.uk/economics 


\title{
Mellowing with tenure? Socialization increases prosocial behavior in public organizations
}

\author{
Sheheryar Banuri \& Philip Keefer ${ }^{1}$ \\ s.banuri@uea.ac.uk \\ pkeefer@iadb.org
}

May 2016

\begin{abstract}
Recent research suggests that prosocial organizations are likely to have more prosocial employees, and that this match plays a significant role in organization contracting practices and productivity - for example, in government. Evidence suggests that selection plays a role: prosocial employees are more likely to join prosocial organizations. In this paper, we ask whether prosocial behavior increases with tenure in prosocial organizations. Using a unique sample of nearly 300 midcareer Indonesian public officials, we find that subjects with longer tenure in the public sector exhibit greater prosocial behavior.
\end{abstract}

1 Banuri: School of Economics and Centre for Behavioral and Experimental Social Science, University of East Anglia, Norwich, UK, NR4 7TJ (e-mail: s.banuri@uea.ac.uk); Keefer: Inter-American Development Bank, 1300 New York Avenue, N.W., Washington, DC 20577 (e-mail: pkeefer@iadb.org). The authors have no relevant or material financial interests that relate to the research described in this paper. We are grateful to Ghazala Mansuri for extremely helpful discussions; to Dr. Muhammad Taufiq at STIA, and Maria Tambunan at the World Bank; and to Eric McLester for his invaluable help in running the sessions. 


\section{Introduction}

In his extensive survey of bureaucracy in the United States, James Q. Wilson (1989) found incomplete contracts, low monitoring, and weak incentives. This led him to speculate why bureaucrats exerted any effort at all, to which the literature has responded by pointing to the prosocial motivation of public sector workers (Banuri and Keefer, 2016; Carpentar and Gong, 2014; Gerhards, 2015; Dur and Zoutenbier, 2014; Smith and Cowley, 2011; Buurman et al., 2012; Gregg et al. 2011; Serra et al. 2011; among others). Effort in the presence of weak monitoring and lowpowered incentives implies that government employees exert effort because they are prosocially motivated to serve the public interest. Considerable attention has been devoted to the question of whether workers in prosocial organizations exhibit higher degrees of prosocial behavior, with significant evidence existing in favor of it. One question that has received much less attention, however, is whether prosocial behavior increases with exposure in prosocial organizations. That is, do workers in prosocial organizations become more prosocial over time?

The analysis in this paper suggests that they do, based on novel evidence from lab games with mid-career public officials in Indonesia. ${ }^{2}$ All subjects participated in a variation of the dictator "game" that precisely measured their prosocial behavior: they received a sum of money and were told that they could give as much of it as they wanted to the Indonesian Red Cross, keeping the rest for themselves. We find that subjects with longer tenures in the public sector donated more to the Indonesian Red Cross.

\footnotetext{
2 Our unique study setting, Indonesia, allows us to assess prosocial behavior of government employees in an organizational environment that is quite different from that of the developed country public sectors utilized in prior research (Gregg et al. 2011; Buurman et al. 2012). For example, Indonesia lies in the middle of the distribution of countries in terms of government effectiveness (percentile rank of 47.8 for 2010) according to world governance indicators (Kaufmann, Kraay, Mastruzzi 2009). This allows for greater generalizability of the findings to other developing countries.
} 
The results contribute to research on prosocial motivation among public sector employees, and the mechanism through which they come to be more prosocial. Prior research finds evidence for selection effects (organizations attract workers who share their mission orientation - Banuri and Keefer, 2016; Besley and Ghatak, 2005; Gregg et al. 2011; Serra et al. 2011). However, a growing literature also suggests that individual norms evolve over time as a function of the other individuals with whom they are in contact - their families, but also the organizations in which they are active (Dohmen et al. 2012; Tabellini, 2008; Bisin and Verdier, 2001; Bulte and Horan, 2011). This literature implies that individuals in organizations with a prosocial mission become more prosocial over time. Evidence documenting this "socialization" is sparse.

Our subject pool allows us to estimate a socialization effect, by testing whether longerserving mid-career public employees exhibit greater prosocial behavior. The 293 subjects in this pool were mid-career government employees attending night school at the College of Administrative Science (in Bahasa: Sekolah Tinggi Ilmu Administrasi - STIA), a government-run college for public administrators.

The literature has argued that prosocial behavior should be greatest in organizations that have a prosocial mission and pay lower wages than the private sector (Frey, 1997; Francois, 2000; Besley and Ghatak, 2005; Brewer and Selden, 1998; Crewson, 1997; Perry, 1996; Perry and Wise, 1990; Sheehan, 1996; Tirole, 1994; Wilson, 1989). A key insight of this literature is that organizations that can attract individuals who share the organization's mission can undertake activities at lower costs and reduce the costs of shirking (Besley and Ghatak, 2003, 2005; Delfgaauw and Dur, 2007; Dixit, 2002; Francois, 2007; among others). Prendergast (2007) argues, though, that prosociality in government officials can lead to excessive generosity towards the beneficiaries of government programs, a prediction that underlines the need for evidence on whether government 
officials are, indeed, more prosocial. Studies also show the importance of mission on worker occupational choices and job satisfaction (Serra et al. 2011; Malka and Chatman, 2003).

Prior research, using the World Values Surveys (WVS), finds differences between private and public sector respondents. In the WVS, respondents classify themselves as public, private or NGO sector employees. The public sector respondents are likely to be from diverse public sector organizations, including those that do not have a direct "caring" mission. Dur and Zoutenbier (2014) find that public sector respondents indicate greater willingness to help people who are nearby, an effect that increases when respondents report greater confidence in political parties. Smith and Cowley (2011) find that public sector respondents to the WVS are more likely to say that they most value a job that is important and provides a feeling of accomplishment, which strengthens when respondents perceive less corruption. Our analysis extends these findings with a behavioral measure of prosocial preferences that is directly related to the work of national government officials and with suggestive evidence that these differences emerge in part because of socialization.

\section{Design}

This review of the literature points to the main open question, which our subject pool and design allow us to address: are individuals who work in government ministries socialized into exhibiting stronger prosocial behavior over time? Testing this hypothesis requires an accurate measure of prosocial behavior. However, prosocial behavior can be defined in different ways. For example, individuals manifest prosocial behavior when they make sacrifices to provide direct assistance to people (of varying social distance); and when they provide assistance directly or indirectly (such as by donating to organizations that, in turn, assist individuals). We capture a form of prosocial behavior that is most relevant to public employees. First, public employee actions tend to have only an indirect effect on welfare. We therefore measure prosocial behavior using donations to an organization (which directly effects welfare). Second, the public sector operates at a national 
level, and so should the organization receiving donations. Third, the organization should have no ideological attractiveness to potential donors apart from the work it does in providing assistance, and fourth, the organization should be well-known, such that potential donors are all equally familiar with it.

There is just one organization in Indonesia that fits these criteria: the Indonesian Red Cross Society. The mission of the Indonesian Red Cross is not specific to any particular region or type of problem, but rather a general charity that assists with disaster-relief, ambulance services, climate change, disaster preparedness, water, sanitation, HIV/AIDS, Avian FLU and blood donation, among other activities.

To measure prosocial behavior, we asked subjects to play a version of the standard dictator "game." Normally, it is played with two players, one of whom is given an endowment of $\$ \mathrm{X}$. The first player can transfer any proportion of the $\$ X$ to the other player. Standard results for this game show that individuals (on average) give about 20 percent of their endowment to the other player (Camerer, 2003). We change the standard setup by replacing the second player with the Indonesian Red Cross Society. ${ }^{3}$

Our sample of mid-career public officials, is drawn from students attending the Sekolah Tinggi Ilmu Administrasi (STIA), a college of continuing education run by the government (in English: the College of Administrative Sciences). ${ }^{4}$ Its students are current employees of various ministries in Indonesia; study at the college enhances students' chances for promotion. Some of the students, particularly from regional governments in Indonesia, are on leave from their current

\footnotetext{
3 A large literature in behavioral economics uses the dictator game as its core measure of altruism and pro-sociality (Forsythe et al 1994; Eckel and Grossman, 1996; Whitt and Wilson, 2007; among many others). Previous research has also replaced the recipient of the dictator game from a student to a charitable organization (Eckel and Grossman, 1996; Li et al, 2011; Carpenter et al. 2008, among others).

4 See Alatas et al. (2009) for other experimental work involving subjects sampled from this institution. For more on the institution itself, see: http://stialan.ac.id/
} 
positions at their respective ministries, Most of our subjects, though, were taking evening classes to earn diplomas in administrative sciences, attending class at the end of their regular workday. This sample is particularly useful since it includes individuals with longer and shorter tenure in government and from various ministries, allowing us to evaluate whether work in government socializes employees to increase prosocial behavior. Table 1 provides the descriptive statistics for the sample.

Selection bias is a natural concern with the interpretation of the results we present below. Ideally, we would track the change in prosociality over time among individuals who enter the public sector at the same time. This empirical setting has eluded all prior researchers, and us. Short of this, however, our STIA sample allows us to provide some reassurance that the results we present below are not driven by attrition. If it were the case that attrition were high in the Indonesian public sector, and only the most prosocial individuals remain in the public sector, then on average it could be the case that a sample of Indonesian public sector workers with shorter tenures would necessarily be less prosocial than a sample of longer-tenured workers. Two facts argue against this interpretation, however.

First, students at STIA are less likely to reflect selection effects. Even if attrition were in general a problem in Indonesia, and less prosocial individuals left the public service early in their careers, the STIA students are least likely to be in that group. Study at STIA is not only costly for them, at least in terms of effort and time, but it is uniquely useful for the public sector career. Individuals set upon leaving the public sector would be unlikely to invest in training to accelerate their advancement in the public sector. This makes it more plausible to assume that the STIA students with shorter tenure behave as STIA students with longer tenures would have behaved if we had been able to document their prosociality earlier in their careers. Second, though we could find no official documentation on attrition rates in the public sector, we conducted these lab experiments 
while simultaneously engaged in a very large (and separate) survey exercise of 4,000 Indonesian

public officials, for the Ministry of Human Resources. (MENPAN). All of our interactions with

officials indicated that attrition is low and early departure from the public sector rare.

Table 1: Sample descriptive statistics

\begin{tabular}{|lrrrrr|}
\hline \multicolumn{1}{|c}{ Variable } & Obs & Mean & $\begin{array}{r}\text { Std. } \\
\text { Dev. }\end{array}$ & Min. & Max. \\
\hline Tokens sent to IRCS & 293 & 874.97 & 570.9 & 0 & 2000 \\
Charity effectiveness rating (7 = Very effective) & 291 & 5.47 & 2.11 & 1 & 7 \\
Age (in years) & 291 & 35.68 & 9.77 & 19 & 78 \\
Female (=1) & 291 & 0.42 & 0.5 & 0 & 1 \\
Fairness perceptions & 291 & 5.5 & 2.89 & 0 & 9 \\
State of personal finances (4 = Excellent) & 291 & 2.57 & 0.64 & 1 & 4 \\
Relative family income (5 = Much above & 291 & 2.92 & 0.92 & 1 & 5 \\
average) & 291 & 1.77 & 1.01 & 0 & 3 \\
Help others (3 = Always help others in need) & 291 & 3.37 & 2.91 & 0 & 9 \\
Trust perceptions & 291 & 2.52 & 1.11 & 1 & 5 \\
Education level (5 = Doctorate) & 291 & 10.97 & 9.23 & 0 & 58 \\
Years in public service & 265 & 9.26 & 3.02 & 5 & 17 \\
Rank in ministry (1 = Lowest) & 293 & 3.05 & 1.69 & 1 & 6 \\
Risk preference (6 = Risk seeking) & &
\end{tabular}

Notes: The sample contains 293 subjects that started the experiment, but 2 subjects did not complete the final survey. For the "Rank in ministry" question, 26 responses were indecipherable, and hence coded as missing. The charity effectiveness rating was given by how strongly subjects agreed with the following statement: "The Indonesian Red Cross provides effective assistance to needy people in Indonesia." Fairness perceptions were measured by responses to the question "Do you think that most people would try to take advantage of you if they got the chance, or would they try to be fair?" Trust perceptions were measured by responses to the question "In general, would you say that most people can be trusted, or that you need to be very careful in dealing with people?" Rank in ministry was measured by response to "Please indicate your rank (golongan) in your ministry." Our risk elicitation method was based on an incentivized measure adapted from Eckel and Grossman (2008), asking subjects to select one from six possible 50-50 gambles, with higher numbered gambles containing high returns with high variance.

Sessions were conducted with 293 students at their institution in March 2012. All

instructions were computerized, with experimenters on hand to address any questions. Instructions

were translated from English to Bahasa, and then back-translated to check for consistency. Subjects

were recruited using announcements with the aid of students and instructors at each location.

Subjects were paid a 100,000 IDR (\$10.66) show-up fee. ${ }^{5}$ The sessions consisted of a number of

games, but always began with the dictator task. All earnings were expressed in tokens, with an

5 This amount was equivalent to their meeting allowance, and was required for them to attend the session. 
exchange rate of 8.33 IDR per token. The stake size for the dictator game, was 2000 tokens $(16,666$ IDR - \$1.78).6 Figure 1 displays the structure of the overall experiment (see Banuri and Keefer, 2016 for results of the larger study). After the dictator stage, subjects undertook a series of real effort tasks and an incentivized risk preference measure, before taking the exit survey.

Figure 1: Structure of the session

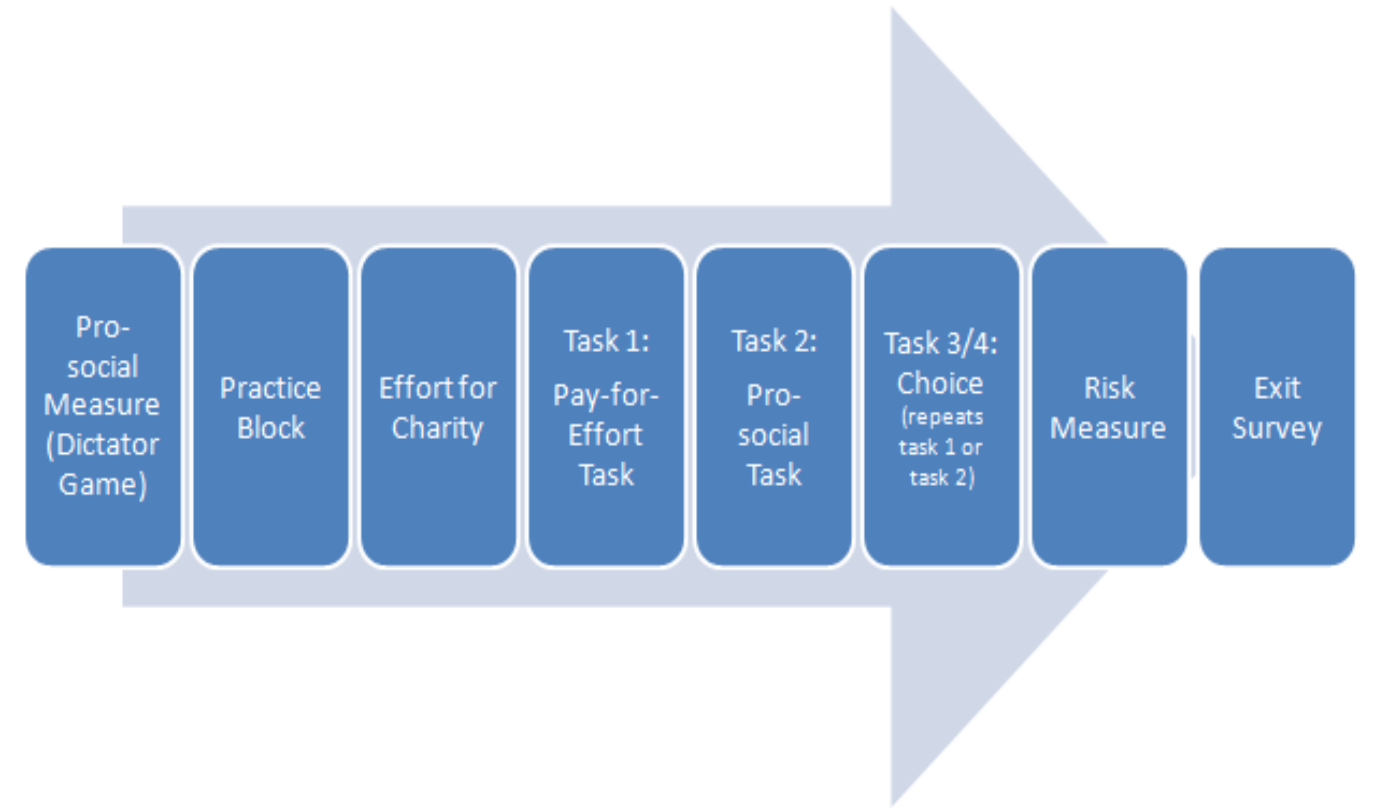

In order to make payments, at the end of a session we asked for a volunteer from the

session. The volunteer stayed behind to verify payment to the charity. Once all subjects were paid, the volunteer added up the total donation to the charity from the session and filled out a cash deposit slip for PT. Bank Rakyat Indonesia. Deposits were made in the presence of the volunteer once per day in cash at the closest bank location. All subjects were informed of this procedure in the instructions at the beginning of the session.

\footnotetext{
6 Income per capita in Indonesia is approximately $\$ 3,000$; this amount is approximately 20 percent of daily income per capita. The average cost of lunch at the local cafeteria was approximately 15,000 IDR. Therefore, we are confident that the stakes were not trivial for the subjects.
} 


\section{Results}

The central question we investigate is whether individuals increase prosocial behavior in organizations with prosocial missions. Figure 1 provides the distribution of tokens sent in the dictator game across all subjects in the sample. The median donation was an equal split (subjects donated 1,000 tokens and kept 1,000 tokens), with the distribution skewed towards zero. Donations were higher in this sample (compared with other studies), perhaps reflecting the fact that our subjects are mid-career (rather than students), with higher disposable incomes, and (potentially) the high show-up fee relative to the dictator game endowment.

Figure 2: Distribution of tokens sent to the IRCS

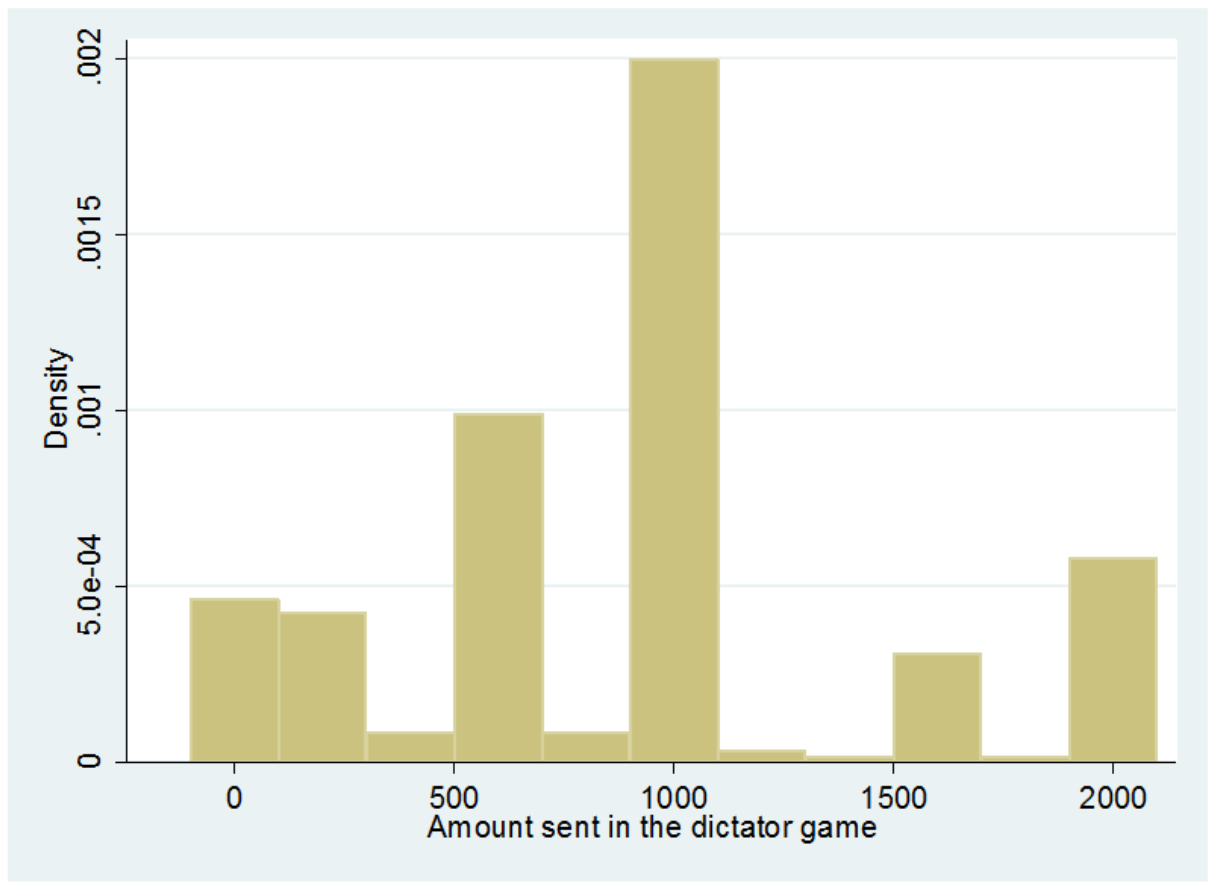

Because our data are censored at 0 and 2,000 tokens, we use a Tobit specification to test whether longer-tenured government employees send more money to the Indonesian Red Cross in the dictator game. If socialization occurs, prosocial behavior (i.e. dictator giving) should rise with length of service. Hence, we regress the amount sent in the dictator game on our main independent variable, years worked in the public sector. The results are presented in Table 2. 
The key difficulty with isolating the effect of length of service is to account for various alternative factors that might influence both giving and tenure. For example, Carpenter et al. (2008) use a representative sample of community members to show that older and, less robustly, more educated people give more to charity. Since time in service correlates with age, which itself is associated with prosocial behavior, we add a control for age. Time in service also correlates with income, since promotions in the Indonesian public service are closely tied to seniority and education, so we also control for rank and education level. ${ }^{7}$ These controls allow us to exclude the possibility that more senior officials are more prosocial because they are older or have higher incomes.

The bivariate regression in Model I, including only the length of service as the main explanatory variable, indicates a strong positive correlation between time in service and giving: each additional year of service is associated with an increase of 23.5 tokens given to the Indonesian Red Cross. Model II includes the controls discussed above. Model III adds further controls for gender (females have been known to contribute more in dictator games); social preferences (questions measuring helpfulness, trust and fairness perceptions adapted from the World Values Survey); and two additional controls for income (a question asking subjects to rate their current state of personal finances, and their perceptions of family income relative to other students at the institution). Finally, model IV adds our final controls: subjects' assessment of the effectiveness of the IRCS in serving the people of Indonesia, and our incentivized measure of risk preferences. One might expect older subjects to have more information on (or a better opinion of) the IRCS, which we control through the charity rating variable.

\footnotetext{
7 The ranking system of the Indonesian Public Service is finely graded, allowing us to capture fairly small differences both with respect to job responsibility and salary. It ranges from 1a (lowest) through 4e (highest). We convert those into a straight numeric system where $1 \mathrm{a}=1,1 \mathrm{~b}=2$, etc. The lowest rank in our sample was $2 \mathrm{a}$, while the highest was $4 \mathrm{e}$. The education variable is coded as $1=$ high school graduate; $2=$ some college; $3=$ bachelors; $4=$ masters; $5=$ doctorate.
} 
Most notably, in all specifications, the coefficient on the years in service variable is positive and significant $(\mathrm{p}<0.05)$, and is 20 tokens on average $(1 \%$ of the endowment) for each year spent in the public sector. Controlling for age and rank (our proxy for income) does not change the results substantially. Rank is positive but not significant, indicating that giving does not increase with income or seniority. Older subjects give less, though not significantly so.

Table 2: Charitable donations

\begin{tabular}{|c|c|c|c|c|}
\hline \multicolumn{5}{|c|}{ Dependent Variable: Amount Sent to Charity in Dictator Game } \\
\hline & $\mathrm{I}$ & II & III & IV \\
\hline Service (in years) & $\begin{array}{r}23.56^{* * *} \\
(4.35)\end{array}$ & $\begin{array}{r}22.85^{* *} \\
(8.99)\end{array}$ & $\begin{array}{r}21.15^{* *} \\
(8.87)\end{array}$ & $\begin{array}{r}19.00^{* *} \\
(8.56)\end{array}$ \\
\hline Rank in ministry & & $\begin{array}{r}13.59 \\
(26.77)\end{array}$ & $\begin{array}{r}18.06 \\
(26.38)\end{array}$ & $\begin{array}{r}23.61 \\
(25.46)\end{array}$ \\
\hline Age (in years) & & $\begin{array}{l}-2.98 \\
(8.00)\end{array}$ & $\begin{array}{l}-3.45 \\
(7.90)\end{array}$ & $\begin{array}{l}-1.66 \\
(7.63)\end{array}$ \\
\hline $\begin{array}{l}\text { Education Level } \\
\qquad 1=\text { High School; } 5=\text { Doctorate }\end{array}$ & & $\begin{array}{r}28.33 \\
(58.20) \\
\end{array}$ & $\begin{array}{r}20.32 \\
(57.28) \\
\end{array}$ & $\begin{array}{r}14.18 \\
(55.26) \\
\end{array}$ \\
\hline $\begin{array}{l}\text { Gender (D) } \\
1=\text { Female }\end{array}$ & & & $\begin{array}{r}-5.61 \\
(82.37) \\
\end{array}$ & $\begin{array}{r}18.85 \\
(79.58) \\
\end{array}$ \\
\hline $\begin{array}{l}\text { Help others } \\
\quad 3=\text { Always help others in need }\end{array}$ & & & $\begin{array}{r}-19.81 \\
(41.48)\end{array}$ & $\begin{array}{l}-19.86 \\
(40.30)\end{array}$ \\
\hline $\begin{array}{l}\text { Fairness perceptions } \\
\qquad 9=\text { Believes others are fair }\end{array}$ & & & $\begin{array}{r}19.12 \\
(14.55)\end{array}$ & $\begin{array}{r}22.22 \\
(14.06)\end{array}$ \\
\hline Trust perceptions & & & $35.82^{* *}$ & $34.37 * *$ \\
\hline $\begin{array}{l}\qquad 9=\text { Believes others are } \\
\text { trustworthy }\end{array}$ & & & $(14.57)$ & $(14.07)$ \\
\hline $\begin{array}{l}\text { State of personal finances } \\
4=\text { Excellent }\end{array}$ & & & $\begin{array}{r}-142.35^{*} \\
(74.04)\end{array}$ & $\begin{array}{r}-115.74 \\
(71.60)\end{array}$ \\
\hline Family income (relative to others) & & & 26.13 & 14.91 \\
\hline $5=$ Much above average & & & $(49.57)$ & $(47.88)$ \\
\hline Charity effectiveness rating & & & & 83.97 *** \\
\hline $7=$ Very effective & & & & (19.93) \\
\hline Risk preference & & & & $46.09 * *$ \\
\hline $6=$ Risk seeking & & & & $(23.29)$ \\
\hline Constant & $\begin{array}{r}625.15^{* * *} \\
(59.98) \\
\end{array}$ & $\begin{array}{r}568.31^{* *} \\
(218.24) \\
\end{array}$ & $\begin{array}{r}680.85^{* *} \\
(272.93) \\
\end{array}$ & $\begin{array}{r}-67.07 \\
(307.91) \\
\end{array}$ \\
\hline R-Squared & 0.01 & 0.01 & 0.01 & 0.02 \\
\hline P-value & 0.000 & 0.000 & 0.000 & 0.000 \\
\hline Left censor & 18 & 15 & 15 & 15 \\
\hline Right censor & 31 & 31 & 31 & 31 \\
\hline Observations & 290 & 264 & 264 & 264 \\
\hline
\end{tabular}

Notes:

a Tobit regressions with censoring at 0 and 2000. Dependent variable is the amount donated to the Indonesian Red Cross in the dictator game.

b Results are robust to OLS with and without rank fixed effects.

c $* 10 \%, * * 5 \%, * * * 1 \%$ significance level. Standard errors in parentheses. 
d Due to undecipherable responses to the question on the subjects rank in their ministry, 26 observations are dropped between models I and II. Furthermore, one 33 year old subject reporting 58 years of service in the public sector is dropped from the analysis (results are robust to his inclusion, however).

Most control variables are insignificant. Importantly, however, giving is significantly higher when subjects give a higher individual assessment of the effectiveness of the charity $(p<0.01)$. Controlling for other measures that capture income (e.g., rank), giving is negatively related to subjects perceptions of the current state of their personal finances $(p<0.1)$. While contrary to expectations, it is possibly the case that higher-ranked individuals who experience financial shocks give more out of empathy with the beneficiaries of the Indonesian Red Cross. Subjects belonging to families with higher relative income levels donate more, but this is not significantly different from zero. Risk-averse individuals appear to give significantly less. And subjects who express greater trust in others given more, consistent with earlier findings of the relationship between trust and altruism (Cox 2004). However, our main result of increased giving with years of service remains robust to all of these controls.

The results support the hypothesis that increased exposure in prosocial organizations increases prosocial behavior. An alternative explanation, though, is that earlier cohorts of public officials were more prosocial than the cohorts that followed them. This is a less plausible explanation, however, since it requires that the decline in prosocial behavior of successive cohorts be monotonic. When we include dummy variables for the different years in which our subjects joined the public sector, we confirm that no year dummy is significantly smaller than the dummies for later years, and in most cases is significantly larger. We cannot exclude that, indeed, such a monotonic decline occurred; if it did, this would, itself be a remarkable occurrence. As a further robustness check we include dummy variables for age (instead of as a control). Our results remain robust to this alternate specification. 
It is, finally, possible that subjects with greater time spent in the public sector are more appreciative of the work of the IRCS and hence give more. To ensure this is not the case, we run a pairwise correlation between years of service and charity rating. We find no significant relationship between the two variables $(p=0.6)$.

\section{Conclusion}

Using a novel pool of public officials in Indonesia, we find evidence for socialization of prosocial behavior in the public sector. Theory and prior empirical research have concluded that prosocial behavior should emerge in organizations that have a direct "caring" social mission. In light of this, our results are even more striking. Prosocial behavior seems to increase even in organizations that are distant from "caring" functions. In countries where the private sector is less prosocial, or where few prosocial organizations exist, prosocial individuals might gravitate even to government ministries with only weakly prosocial missions, and increase prosocial behavior over time.

We find that individuals with greater experience in government employment are also more prosocial. Subjects with longer experience in government exhibit more prosocial behavior, making larger donations to charity. We cannot claim that students at STIA are a random sample of the larger Indonesian public sector. However, we can rule out some sources of selection bias. Attrition is unlikely to account for this: our novel setting in the College of Administrative Science yields a subject pool that is less likely to be looking to exit, and attrition rates in general in the Indonesian public service appear to be low. The result is also unlikely to be the result of a cohort effect: while it is possible that individuals who joined the government earlier had greater prosocial motivation than those who joined more recently, our evidence suggests that this could only be the case if 
successive cohorts were each less prosocial than the last. The results therefore contribute to our growing understanding of the socializing effects of public service. 


\section{References}

Alatas, V., Cameron, L., Chaudhuri, A., Erkal, N., \& Gangadharan, L. (2009). "Subject pool effects in a corruption experiment: A comparison of Indonesian public servants and Indonesian students." Experimental Economics 12(1): 113-132.

Banuri, Sheheryar, and Philip Keefer (2016). "Pro-social motivation, effort and the call to public service." European Economic Review 83(C): 139-164.

Besley, Timothy and Maitreesh Ghatak (2003). "Incentives, choice, and accountability in the provision of public services." Oxford Review of Economic Policy 19(2):235-249. (2005). "Competition and incentives with motivated agents." American Economic Review 95(3):616-636.

Bisin, Alberto, and Thierry Verdier (2001). "The Economics of Cultural Transmission and the Dynamics of Preferences.” Journal of Economic Theory 97: 298-319.

Brewer, Gene A. and Sally Coleman Selden (1998). "Whistle blowers in the federal civil service: New evidence of the public service ethic." Journal of Public Administration Research and Theory 8(3):413-440.

Bulte, Erwin H., and Richard D. Horan (2011). "Intergenerational Transmission of Preferences." Economics Letters 112(1): 85-87.

Buurman, Margaretha, Josse Delfgaauw, Rober Dur and Seth Van den Bossche (2012). "Public sector employees: Risk averse and altruistic?" Journal of Economic Behavior and Organization 83(3):279-291.

Camerer, Colin (2003). Behavioral Game Theory: Experiments in Strategic Interaction. Princeton, NJ: Princeton Univ. Press.

Carpenter, Jeffrey, Cristina Connolly and Caitlin Myers (2008). "Altruistic behavior in a representative dictator experiment." Experimental Economics 11:282-298.

Carpenter, Jeffrey, and Erick Gong (2016). "Motivating Agents: How much does the mission matter?." Journal of Labor Economics 34(1): 211-236.

Cox, James C. (2004). "How to identify trust and reciprocity." Games and Economic Behavior 46(2):260-281.

Crewson, Philip E. (1997). "Public-service motivation: Building empirical evidence of incidence and effect." Journal of Public Administration Research and Theory 7(4):499-518.

Delfgaauw, Josse and Rober Dur (2007). "Signaling and screening of workers' motivation." Journal of Economic Behavior and Organization 62(4):605-624.

Dixit, Avinash (2002). "Incentives and organizations in the public sector: an interpretative review." The Journal of Human Resources 37(4):696-727.

Dohmen, Thomas, Armin Falk, David Huffman, and Uwe Sunde. (2012). "The Intergenerational Transmission of Risk and Trust Attitudes." The Review of Economic Studies 79(2): 645-677.

Dur, Robert and Robin Zoutenbier (2014). "Working for a Good Cause." Public Administration Review 74(2): 144-155..

Eckel, Catherine C. and Phillip J. Grossman (1996). "Altruism in anonymous dictator game." Games and Economic Behavior 16:181-191.

Forsythe, Robert, Joel L. Horowitz, N. E. Savin and Martin Sefton (1994). "Fairness in simple bargaining experiments." Games and Economic Behavior 6:347-369.

Francois, Patrick (2000). “Public service motivation' as an argument for government provision.” Journal of Public Economics 78:275-299. (2007). "Making a difference." The RAND Journal of Economics 38(3): 714-732.

Frey, Bruno S. (1997). Not Just for the Money: An Economic Theory of Personal Motivation. Cheltenham: Edward Elgar Press. 
Gerhards, Leonie (2015). "The incentive effects of missions-Evidence from experiments with NGO employees and students." European Economic Review 79: 252-262.

Gregg, Paul, Paul A. Grout, Anita Ratcliffe, Sarah Smith and Frank Windmeijer (2011). "How important is pro-social behaviour in the delivery of public services?" Journal of Public Economics 95(7-8):758-766.

Kaufmann, Daniel, Aart Kraay and Massimo Mastruzzi. (2009). "Governance matters VIII: Aggregate and individual governance indicators 1996-2008.” World Bank Policy Research Working Paper No. 4978.

Li, Sherry Xin, Catherine C. Eckel, Phillip J. Grossman and Tara Larson Brown (2011). "Giving to government: Voluntary taxation in the lab.” Journal of Public Economics 95(9-10):1190-1201.

Malka, Ariel and Jennifer A. Chatman (2003). "Intrinsic and extrinsic work orientations as moderators of the effect of annual income on subjective well-being: A longitudinal study." Personality and Social Psychology Bulletin 29(6):737-746.

Perry, James L. (1996). "Measuring public service motivation: An assessment of construct reliability and validity." Journal of Public Administration Research and Theory 6(1):5-22.

Perry, James L. and Lois Recascino Wise (1990). “The motivational bases of public service.” Public Administration Review 50(3):367-373.

Prendergast, Canice (2007). "The motivation and bias of bureaucrats." American Economic Review 97(1):180-196.

Serra, Danila, Pieter Serneels and Abigail Barr (2011). "Intrinsic motivations and the non-profit health sector: Evidence from Ethiopia." Personality and Individual Differences 51(3):309 - 314.

Sheehan, R. (1996) "Mission Accomplishment as Philanthropic Effectiveness: Key Findings from the Excellence in Philanthropy Project.” Non-profit and Voluntary Sector Quarterly 25 (1): 110_ 23.

Smith, Sarah and Edd Cowley (2011). "Who works in the public sector? Evidence from the World Values Survey." The Centre for Market and Public Organization Working Paper No. 11/268 (August).

Tabellini, Guido E. (2008). "The Scope of Cooperation: Values and Incentives." Quarterly Journal of Economics 123(3): 905-950.

Tirole, Jean. (1994). "The internal organization of government." Oxford Economic Papers 46(1):1-29.

Whitt, Sam and Rick K. Wilson (2007). "The dictator game, fairness and ethnicity in postwar Bosnia." American Journal of Political Science 51(3):655-668.

Wilson, James Q. (1989). Bureaucracy: What Governments Do and Why they Do It. New York: Basic Books. 


\section{Appendix A - Instructions}

\section{Dictator Game Instructions Page 1 of 2:}

On this page, we have a description of the charity that you will be paired with. Please read the description of this charity.

Indonesian Red Cross Society (Palang Merah Indonesia): The Indonesian Red Cross Society (IRCS) is a humanitarian organization and a member of International Federation of Red Cross and Red Crescent Societies. The IRCS was created on September 17th, 1945, exactly 1 month after Indonesia's independence. President Soekarno ordered its inception when a battle between Indonesian soldiers and allied troops broke out, leaving many wounded, on September 3rd, 1945. Based on its performance, IRCS received international recognition in 1950 when it was accepted as a member of the International Red Cross and achieved its legal status through Presidential Decree Number 25 Year 1959, which was later reinforced by Presidential Decree Number 245 Year 1963. The IRCS central headquarters is located at Jl. Jenderal Gatot Soebroto Kav. 96, Jakarta 12790.8 Activities undertaken by the IRCS include:

PMI in Disaster Response: A variety of geographical and geological factors, as well as demographic conditions affect the high frequency of natural disasters in Indonesia. In accordance with the duties and functions of the organization, the Red Cross Indonesia is obliged to provide help and assistance during an emergency to those in need, in a professional manner based on the basic principles of the International Red Cross and Red Crescent Movement. Disaster response activities include evaluation of preferred PMI rescue and first aid by giving priority to the vulnerable, such as pregnant women, children, and seniors.

Water and Sanitation for Vulnerable Communities: In accordance with the Indonesian Red Cross policy 1999-2004 and the IFRC Strategy 2010 for public health programs, PMI is helping vulnerable groups promote public health through improved hygiene, clean water and sanitation facilities; making it an integrated program with community development in the field of first aid, disaster management, and development of water sanitation programs for vulnerable groups of people who have difficulty accessing clean water and people in disaster/conflict refugee camps.

\footnotetext{
8 Description from Wikipedia; Accessed on January 24th 2012 . Link: http://en.wikipedia.org/wiki/Indonesian_Red_Cross_Society
} 


\section{Dictator Game Instructions Page 2 of 2:}

Now we would like to ask you whether you would like to make a donation to the charity. You are given 2000 tokens. You can choose to send none, some, or all the tokens to the charity. This amount will be added to the final total sent to the charity and you will keep the rest. Please enter the amount you would like to send and the amount you would like to keep below. Note that both these amounts should add to 2000 .

Tokens you would like to keep:

Tokens you would like to send to the charity: 